\title{
PENERAPAN METODE PEMBELAJARAN THINK PAIR SHARE PADA MATA PELAJARAN PKn SEBAGAI UPAYA PENINGKATAN MOTIVASI BELAJAR SISWA KELAS X AKUNTANSI DI SMK BHINA KARYA I RONGKOP
}

\author{
Oleh : \\ Nur Endah Luarsi \\ Universitas Cokroaminoto Yogyakarta
}

\begin{abstract}
Abstrak
Penelitian ini merupakan Penelitian Tindakan Kelas (PTK) yang bertujuan untuk mengetahui peningkatkan motivasi belajar siswa kelas X Akuntansi di SMK Bhina Karya I Rongkop dalam mata pelajaran PKn dengan menggunakan metode pembelajaran Think Pair Share. Penelitian ini dilakukan dalam bentuk kolaborasi yang dilaksanakan dalam dua siklus. Subjek penelitian ini adalah siswa kelas X Akuntansi SMK Bhina Karya I Rongkop Tahun Pelajaran 2015/ 2016 yang terdiri dari 22 orang. Teknik pengumpulan data dalam penelitian ini adalah observasi, angket dan wawancara.Teknik analisis data yang digunakan dalam penelitian ini yaitu teknik analisis deskriptif kuantitatif dengan persentase. Kesimpulan dari penelitian ini adalah bahwa pelaksanaan pembelajaran dengan metode Think Pair Share dapat meningkatkan motivasi belajar siswa. Hal ini terbukti dari angket yang diolah dari pra siklus ke siklus I sebesar 4,40\% dan dari siklus I ke siklus II terjadi peningkatan 4,07\%. Sedangkan berdasarkan data observasi dari siklus I ke siklus II terjadi peningkatan sebesar 4,26\% dimana skor pada siklus I sebesar $74,15 \%$ meningkat menjadi $78,14 \%$. Hal ini juga diperkuat dengan wawancara yang dilakukan, dimana data yang diperoleh menunjukan hasil yang sama dengan data angket.
\end{abstract}

Kata Kunci: Metode, Think Pair Share, PKn, Motivasi, Siswa

\section{Pendahuluan}

Pendidikan merupakan kata yang sangat diagungkan dalam suatu peradaban bangsa. Pendidikan telah memberikan banyak manfaat bagi perkembangan ilmu pengetahuan di dunia. Pendidikan merupakan usaha manusia agar dapat mengembangkan potensi dirinya, antara lain melalui proses pembelajaran di sekolah, baik Sekolah Dasar (SD), Sekolah Menengah Pertama (SMP), Sekolah Menengah Umum (SMU), maupun Sekolah Menengah Kejuruan (SMK), serta Perguruan Tinggi (PT), yang masing-masing memiliki visi, misi dan tujuan yang spesifik. Proses pendidikan itulah yang akan banyak dinilai karena proses pendidikan sebagai salah satu titik tolak keberhasilan dan kemajuan suatu bangsa. Banyak cara yang telah dilakukan oleh 
manusia agar pendidikan berhasil, salah satunya pendidikan sepanjang hayat. Pendidikan sepanjang hayat juga disebut pendidikan seumur hidup atau Long Life Education. Pendidikan ini menuntut agar pendidikan tidak hanya dilakukan pada masa anak-anak atau pada masa remaja saja, melainkan pendidikan mulai dari anak-anak, remaja, dewasa, sampai masa tua, bahkan ada yang menyebut dari masa dalam kandungan ibu, pendidikan sudah harus diberlakukan.

Perkembangan ilmu pengetahuan dan teknologi menuntut pemerintah Indonesia senantiasa melakukan pembaharuan dalam sistem pendidikan nasional terutama dalam strateginya, sehingga hampir setiap lima tahun pemerintah mengganti kurikulum yang sampai saat ini dinamakan Kurikulum Tingkat Satuan Pendidikan (KTSP). Sekolah Menengah Kejuruan (SMK) sekarang sudah memberlakukan KTSP. Dalam mata pelajaran PKn, salah satu strategi pembelajaran yang digunakan adalah Think Pair Share (TPS) atau berpikir berpasangan berbagi adalah merupakan jenis pembelajaran kooperatif yang dirancang untuk mempengaruhi pola interaksi siswa. Pertama kali dikembangkan oleh Frang Lyman dan koleganya di Universitas Maryland. Think Pair Share merupakan suatu cara yang efektif untuk membuat variasi suasana pola diskusi kelas. Dengan asumsi bahwa semua diskusi membutuhkan pengaturan untuk mengendalikan secara keseluruhan, dan prosedur yang digunakan dalam Think Pair Share dapat memberi siswa lebih banyak waktu berpikir, untuk merespon dan saling membantu.

Mata Pelajaran Pendidikan Kewarganegaraan merupakan mata pelajaran yang memfokuskan pada pembentukan warga negara yang memahami dan mampu melaksanakan hakhak dan kewajibannya untuk menjadi warga negara yang baik, yang cerdas, terampil, dan berkarakter yang diamanatkan oleh Pancasila dan UUD 1945. Pendidikan Kewarganegaraan (Citizenship Education) merupakan mata pelajaran yang memfokuskan pada pembentukan diri yang beragam dari segi agama, sosio-kultural, bahasa, usia, dan suku bangsa. Indikator yang harus dicapai siswa, merupakan indikator yang dalam proses pemahamannya memerlukan suatu pemahaman yang dibahas secara bersama sama, terdapat interaksi antar siswa di dalamnya. Mengingat pentingnya peranan mata pelajaran ini, menuntut guru dan sekolah berusaha mengatasi kesenjangan hasil belajar siswa dengan berbagai upaya perbaikan pendidikan, diantaranya dengan metode Think Pair Share . Berdasarkan hasil wawancara dengan guru PKn di SMK Bhina Karya I Rongkop, dalam evaluasi nilai rata-rata siswa belum mencapai nilai kriteria ketuntasan minimal (KKM), dapat diamati pada tabel 1. 
Tabel 1. Nilai semester gasal kelas X Akuntansi

\begin{tabular}{|c|c|c|c|c|c|}
\hline No & Mata Pelajaran & $\begin{array}{c}\text { Nilai } \\
\text { Rata-rata }\end{array}$ & $\begin{array}{c}\text { Jumlah siswa } \\
\text { mencapai } \\
\text { KKM }\end{array}$ & $\begin{array}{c}\text { Jumlah siswa } \\
\text { yang tidak } \\
\text { mencapai KKM }\end{array}$ & Jumlah Siswa \\
\hline 1 & PKn & 74,6 & 9 & 13 & 22 \\
\hline
\end{tabular}

Melihat kondisi di atas, pembelajaran yang terjadi belum menunjukkan proses belajar yang berkualitas serta motivasi belajar siswa yang masih rendah. Hal ini menyebabkan penyerapan materi ajar oleh siswa belum optimal, selanjutnya berujung pada rendahnya hasil belajar siswa yang kemudian perlu dilakukan remidial. Kriteria ketuntasan minimal (KKM) di SMK Bhina Karya I Rongkop, khususnya pada mata pelajaran PKn yaitu 7,5 nilai ini merupakan nilai minimal yang harus dipenuhi siswa. Pelaksanaan remidial memang diperbolehkan dalam pendidikan untuk memenuhi nilai KKM, akan tetapi kemudahankemudahan dalam remidial akan membangun mental siswa yang hanya berorientasi pada nilai. Padahal tujuan utama dari suatu pembelajaran bukanlah semata-mata nilai, namun usaha membelajarkan siswa melalui proses pembelajaran, yang kemudian diukur penguasaannya melalui evaluasi kemudian keluar nilai. Berkaitan dengan hal tersebut, berdasarkan hasil observasi awal ketika guru mengajar, guru masih menerapkan metode pembelajaran konvensional yang hanya berpusat pada guru (Teacher Center Learning/TCL). Metode ceramah cenderung dominan digunakan guru dalam menyampaikan materi pelajaran dan kurang melibatkan siswa. Sehingga siswa kurang termotivasi untuk berfikir lebih aktif dan kreatif. Sebagai akibatnya ketika dilakukan pengamatan ditemukan siswa dalam keadaan kurang optimal seperti: (1) siswa sering menyandarkan kepala di atas meja, menandakan siswa bosan mengikuti pelajaran, (2) siswa sering mengobrol dengan teman satu meja ketika guru menjelaskan pelajaran, (3) bergurau dengan teman yang lain, (4) tidak dapat menjawab pertanyaan yang diajukan, (5) tidak berani bertanya, tidak berani mengemukakan pendapat. Proses pembelajaran yang seperti ini menyebabkan penyerapan materi ajar oleh siswa tidak dapat optimal, karena proses pembelajaran hanya terjadi interaksi satu arah dan kurang melibatkan siswa.

Seharusnya guru dalam penyampaian materi dapat lebih kreatif menerapkan berbagai metode dalam proses pembelajaran yang dapat membangkitkan motivasi belajar siswa disesuaikan dengan kebutuhan materi ajar yang akan disampaikan. Proses pembelajaran akan 
berkualitas apabila pembelajaran tersebut sudah menggunakan sistem pembelajaran yang berpusat pada siswa (Student Center Learning/SCL) dimana dalam proses pembelajaran siswa sepenuhnya melakukan aktifitas belajarnya, melakukan proses berpikir, mencari, mengolah, menganalisis, mengurai, dan menyimpulkan sehingga penyerapan materi ajar oleh siswa dapat dioptimalkan serta dapat menumbuhkan motivasi belajar bagi siswa. "Belajar merupakan suatu proses aktif, belajar adalah proses mereaksi terhadap semua situasi yang ada disekitar individu yang ditandai dengan adanya perubahan pada diri seseorang” (Nana Sudjana 1988:28).

Selama ini guru cenderung kurang memperdulikan apakah siswanya memiliki motivasi dalam belajar, karena yang penting adalah materi yang harus disampaikan selesai. Padahal jika siswa tidak memiliki motivasi yang kuat dalam belajar maka mustahil siswa akan mampu mempelajari bahan ajar dengan baik sehingga prestasi hasil belajar tidak sesuai dengan apa yang diinginkan. Guru hendaknya mampu membangkitkan motivasi belajar siswa, yaitu dengan mengembangkan cara - cara kreatif, diantaranya dengan metode pembelajaran Think Pair Share. Dengan demikian diharapkan siswa akan belajar dengan penuh semangat, sehingga prestasi hasil belajar akan lebih baik.

Berdasarkan permasalahan tentang kurangnya motivasi belajar siswa dalam mata pelajaran PKn yang berimplikasi pada rendahnya prestasi hasil belajar yang diperoleh siswa, maka peneliti tertarik mengambil judul "Penerapan metode pembelajaran Think Pair Share pada mata pelajaran PKn sebagai upaya peningkatan motivasi belajar siswa kelas X Akuntansi di SMK Bhina Karya I Rongkop.”

\section{Kajian Teori}

Metode Pembelajaran Think Pair Share, Menurut Trianto (2007 : 61), Think Pair Share (TPS) atau berpikir berpasangan berbagi adalah merupakan jenis pembelajaran kooperatif yang dirancang untuk mempengaruhi interaksi siswa. Sedangkan menurut Anita Lie (2004 : 57) Think Pair Share merupakan salah satu metode pembelajaran kooperatif sederhana yang memberi kesempatan kepada siswa untuk bekerja sendiri serta bekerja sama dengan orang lain. Dari beberapa pendapat di atas dapat disimpulkan bahwa metode pembelajaran Think Pair Share merupakan pembelajaran kelompok dimana siswa diberi kesempatan untuk berfikir mandiri dan saling membantu dengan teman yang lain. Pembelajaran Think Pair Share merupakan metode 
pembelajaran kooperatif dengan pendekatan struktural. Pendekatan ini memberi penekanan pada penggunaan struktur tertentu yang dirancang untuk mempengaruhi pola interaksi siswa.

Tahapan Think pair share, memiliki prosedur yang ditetapkan secara eksplisit untuk memberi siswa waktu lebih banyak untuk berpikir, menjawab, dan saling membantu (Nurhadi, 2003 : 66). Setelah guru menyajikan suatu topik atau setelah siswa membaca suatu tugas, selanjutnya guru meminta siswa untuk memikirkan permasalahan yang ada dalam topik/bacaan tersebut. Dalam metode ini siswa memikirkan suatu topik, berpasangan dengan siswa lain dan mendiskusikannya, kemudian berbagi dengan seluruh kelas. Menurut Trianto (2007 : 61), dalam bukunya yang berjudul Model-metode pembelajaran inovatif berorientasi konstruktivisik menyebutkan tahap - tahap pembelajaran Think Pair Share adalah sebagai berikut:

\section{1) Berpikir (Thinking)}

Guru mengajukan suatu pertanyaan atau masalah yang dikaitkan dengan pelajaran, dan meminta siswa menggunakan waktu beberapa menit untuk berfikir sendiri jawaban atau masalah. Siswa membutuhkan penjelasan bahwa berbicara atau mengerjakan bukan bagian berfikir.

\section{2) Berpasangan (Pairing)}

Selanjutnya guru meminta siswa untuk berpasangan dan mendiskusikan apa yang telah mereka peroleh. Interaksi selama waktu yang disediakan dapat menyatukan jawaban jika suatu pertanyaan yang diajukan atau menyatukan gagasan apabila suattu masalah khusus yang diidentifikasi. Secara normal guru memberi waktu tidak lebih dari 4 atau 5 menit untuk berpasangan.

\section{3) Berbagi (Sharing)}

Pada langkah akhir, guru meminta pasangan-pasangan untuk berbagi dengan keseluruhan kelas yang telah mereka bicarakan. Hal ini efektif untuk berkeliling ruangan dari pasangan ke pasangan dan melanjutkan sampai sekitar sebagian pasangan mendapat kesempatan untuk melaporkan Arends, (1997) disadur Tjokrodihardjo, (2003).

Metode pembelajaran ini dapat meningkatkan kemampuan komunikasi siswa, karena siswa harus saling melaporkan hasil pemikiran masing - masing dan berbagi (berdiskusi) dengan pasangannya. Selanjutnya pasangan-pasangan tersebut harus berbagi dengan seluruh kelas, jumlah anggota kelompok yang kecil mendorong setiap anggota untuk terlibat secara aktif. 
Kelebihan dan kekurangan Think Pair Share, Menurut Anita Lie (2004 : 57), kelebihan tipe Think Pair Share adalah sebagai berikut:

1) Memungkinkan siswa untuk merumuskan dan mengajukan pertanyaan-pertanyaan mengenai materi yang diajarkan karena secara tidak langsung memperoleh contoh pertanyaan yang diajukan oleh guru, serta memperoleh kesempatan untuk memikirkan materi yang diajarkan.

2) Siswa akan terlatih menerapkan konsep karena bertukar pendapat dan pemikiran dengan temannya untuk mendapatkan kesepakatan dalam memecahkan masalah.

3) Siswa lebih aktif dalam pembelajaran karena menyelesaikan tugasnya dalam kelompok, dimana tiap kelompok hanya terdiri dari 2 orang.

4) Siswa memperoleh kesempatan untuk mempersentasikan hasil diskusinya dengan seluruh siswa sehingga ide yang ada menyebar.

5) Memungkinkan guru untuk lebih banyak memantau siswa dalam proses.

Kelemahan pelaksanan Think Pair Share, menurut Anita Lie menyatakan bahwa kekurangan tipe ini antara lain adalah:

1) Banyak kelompok yang melaporkan dan perlu dimonitor.

2) Lebih sedikit ide yang muncul.

3) Jika ada perselisihan, tidak ada penengah.

Solusi dari peneliti terkait dengan tidak adanya penengah dalam perselisihan ini, maka menjadikan guru sebagai penengahnya.

Alasan peneliti memilih Metode pembelajaran Think Pair Share, merupakan suatu cara yang efektif untuk membuat variasi pola diskusi di kelas. Metode ini dapat memberi siswa lebih banyak waktu berfikir, untuk merespon dan saling membantu. Melalui kegiatan ini, siswa diharapkan saling membantu satu sama lain, sehingga menghasilkan efek positif terhadap peningkatan respon siswa. Dalam metode pembelajaran Think Pair Share siswa secara tidak langsung dilatih dan dididik untuk berlatih berbicara di depan umum yaitu dengan mengutarakan ide atau pendapat dengan pasangannya.

Motivasi Belajar, Menurut Oemar Hamalik (1990:173) menyebutkan bahwa "motivasi adalah menunjuk pada semua gejala yang terkandung dalam stimulasi tindakan kearah tujuan tertentu dimana sebelumnya tidak ada tindakan menuju kearah tujuan tersebut". Pengertian ini menekankan motivasi merupakan proses membangkitkan, mempertahankan dan mengontrol 
minat-minat. Selanjutnya menurut Mc. Donald (dalam Sardiman, 2007 : 73), motivasi adalah perubahan energi dalam diri seseorang yang ditandai dengan munculnya "felling" dan didahului dengan tanggapan terhadap adanya tujuan.

Berdasarkan beberapa pendapat di atas dapat disimpulkan bahwa motivasi merupakan keseluruhan daya penggerak di dalam diri siswa yang menimbulkan, menjamin kelangsungan, dan yang memberikan arah dalam kegiatan belajar. Sehingga tujuan yang diharapkan dapat tercapai dengan baik dan maksimal. Belajar ada sejak manusia dilahirkan sampai usia lanjut, dalam kehidupan sehari-hari manusia banyak melakukan kegiatan yang sebenarnya merupakan suatu gejala belajar. Menurut Slameto, (2010 : 72), "belajar adalah suatu proses usaha yang dilakukan seseorang untuk memperoleh suatu perubahan tingkah laku yang baru secara keseluruhan, sebagai hasil pengalamanya sendiri dalam interaksi dengan lingkunganya." Hal ini menunjukkan bahwa jika seseorang melakukan gejala belajar dengan baik maka terjadi proses perubahan sebagai hasil belajar dan terjadi dalam jangka waktu tertentu. Perubahan dari belum tahu menjadi tahu, belum mampu menjadi mampu adalah perubahan tingkah laku yang menandai telah terjadinya proses belajar. Belajar menurut pengertian secara psikologis, merupakan suatu proses perubahan, yaitu perubahan tingkah laku sebagai hasil dari interaksi dengan lingkunganya dalam memenuhi kebutuhan hidupnya.

Motivasi belajar adalah keseluruhan daya penggerak dari dalam diri siswa yang menimbulkan kegiatan belajar serta memberi arah pada kegiatan belajar (Winkel : 1983). Dalam kegiatan belajar motivasi dapat dikatakan sebagai penggerak dari dalam diri siswa yang menimbulkan kegairahan belajar, menjamin kelangsungan dari kegiatan belajar dan memberi arah pada kegiatan belajar sehingga siswa terdorong untuk bersemangat belajar. Dikatakan keseluruhan karena pada umumnya ada beberapa dorongan yang bersama-sama menggerakkan siswa untuk belajar. Siswa yang memiliki motivasi kuat akan mempunyai banyak energy untuk melakukan kegiatan belajar. Dalam hal ini selaras dengan pendapat Sardiman (1992 : 74) yang menyatakan bahwa "Motivasi akan menyebabkan terjadinya suatu perubahan energi yang ada pada diri manusia sehingga akan bergayut pada persoalan gejala kejiwaan, perasaan dan emosi untuk kemudian bertindak atau melakukan sesuatu semua didorong karena adanya tujuan, kebutuhan atau keinginan”. Berdasarkan uraian tersebut diatas maka dalam proses pendidikan para siswa perlu diberi rangsangan agar timbul motivasi belajar pada dirinya atau perlu 
diciptakan kondisi tertentu sehingga siswa menggerakkan untuk belajar. Hal tersebut dilakukan karena motivasi belajar siswa dapat dirangsang oleh faktor luar. Motivasi belajar adalah keseluruhan daya penggerak didalam diri siswa yang menimbulkan kegiatan belajarserta memberi arah pada kegiatan belajar (Winkel : 1983).

Pembelajaran PPKn, Menurut Depdiknas dalam Kamus Besar Bahasa Indonesia (2005 : 17) belajar berasal dari kata ajar yang berarti petunjuk yang diberikan kepada orang supaya diketahui, sedangkan belajar ialah berusaha memperoleh kepandaian atau ilmu. Wina Sanjaya (2006:57) mengemukakan, belajar adalah proses perubahan tingkah laku. Namun demikian kita sulit melihat bagaimana proses terjadinya perubahan tingkah laku dalam diri seseorang, karena perubahan tingkah laku berhubungan dengan sistem syaraf dan perubahan energi yang sulit dilihat dan diraba. Belajar adalah proses berpikir. Belajar berpikir menekankan kepada proses mencari dan menemukan pengetahuan melalui interaksi antara individu dengan lingkungan. Belajar ialah suatu proses usaha yang dilakukan individu untuk memperoleh suatu perubahan tingkah laku yang relatif menetap, baik yang dapat diamati maupun tidak dapat diamati secara langsung, yaitu tejadi sebagai suatu hasil latihan atau pengalaman dalam interaksinya dengan lingkungan. Belajar bukan hanya mengingat suatu pengetahuan melainkan mengalami suatu kejadian, sehingga siswa harus menguasai melalui latihan - latihan dan perubahan perilaku. Pembelajaran pada hakikatnya adalah proses interaksi antara peserta didik dengan lingkungannya sehingga terjadi perubahan perilaku yang lebih baik. Pendidikan Kewarganegaraan, Menurut Azyumardi Azra Pendidikan Kewarganegaraan adalah pendidikan yang mengkaji dan membahas tentang pemerintahan, konstitusi, lembaga-lembaga demokrasi, rule of law, HAM, hak dan kewajiban warganegara serta proses demokrasi. Sedangkan menurut Zamroni, Pendidikan Kewarganegaraan adalah pendidikan demokrasi yang bertujuan untuk mempersiapkan warga masyarakat berpikir kritis dan bertindak demokratis. Dengan demikian dapat disimpulkan bahwa Pendidikan Kewarganegaraan adalah sebagai wahana untuk mengembangkan kemampuan, watak dan karakter warga negara yang demokratis dan bertanggung jawab.

Ada beberapa hal yang perlu diperhatikan dalam pelajaran PKn dalam rangka "nation and character building":

1) Pertama: PKn merupakan bidang kajian kewarganegaraan yang ditopang berbagai disiplin ilmu yang relevan, yaitu: ilmu politik, hukum, sosiologi, antropologi, psikologi dan disiplin 
ilmu lainnya yang digunakan sebagai landasan untuk melakukan kajian-kajian terhadap proses pengembangan konsep, nilai dan perilaku demokrasi warganegara.

2) Kedua: PKn mengembangkan daya nalar (state of mind) bagi para peserta didik. Pengembangan karakter bangsa merupakan proses pengembangan warga negara yang cerdas dan berdaya nalar tinggi. PKn memusatkan perhatiannya pada pengembangan kecerdasan warga negara (civic intelegence) sebagai landasan pengembangan nilai dan perilaku demokrasi.

3) Ketiga: PKn sebagai suatu proses pencerdasan, maka pendekatan pembelajaran yang digunakan adalah yang lebih inspiratif dan partisipatif dengan menekankan pelatihan penggunaan logika dan penalaran. Untuk memfasilitasi pembelajaran PKn yang efektif dikembangkan bahan pembelajaran yang interaktif yang dikemas dalam berbagai paket seperti bahan belajar tercetak, terekam, tersiar, elektronik, dan bahan belajar yang digali dari ligkungan masyarakat sebagai pengalaman langsung (hand of experience).

4) Keempat : kelas PKn sebagai laboratorium demokrasi. Melalui PKn, pemahaman sikap dan perilaku demokratis dikembangkan bukan semata-mata melalui "mengajar demokrasi" (teaching democracy), tetapi melalui metode pembelajaran yang secara langsung menerapkan cara hidup secara demokrasi (doing democracy). Penilaian bukan semata-mata dimaksudkan sebagai alat kedali mutu tetapi juga sebagai alat untuk memberikan bantuan belajar bagi siswa sehingga lebih dapat berhasil dimasa depan. Evaluasi dilakukan secara menyeluruh termasuk portofolio siswa dan evaluasi diri yang lebih berbasis kelas.

\section{Pembahasan}

Dari penelitian yang dilakukan yang meliputi perencanaan, tindakan, pengamatan dan refleksi telah diperoleh data seperti yang telah diketahui di atas. Pelaksanaan pembelajaran dengan Metode Pembelajaran Think Pair Share (TPS) pada mata pelajaran PKn untuk kelas X Akuntansi di SMK Bhina Karya I Rongkop pada siklus I maupun siklus II menunjukan aktivitasaktivitas yang mencerminkan adanya motivasi untuk belajar. Untuk lebih jelasnya berikut disajikan data motivasi belajar PKn siswa sebelum penelitian, Siklus I dan siklus II. 
Tabel 14. Perbandingan Skor Motivasi Belajar PKn berdasarkan angket yang diberikan kepada siswa pada pra penerapan, siklus I dan Siklus II

\begin{tabular}{|l|l|l|l|l|l|l|l|}
\hline \multirow{2}{*}{ Indikator } & \multicolumn{3}{|l|}{ Skor \% } & \multicolumn{3}{l|}{ Peningkatan (\%) } \\
\cline { 2 - 7 } & Pra & $\begin{array}{l}\text { Siklus } \\
\text { I }\end{array}$ & $\begin{array}{l}\text { Siklus } \\
\text { II }\end{array}$ & Pra- Siklus I & \multicolumn{2}{l|}{ Siklus I-II } \\
\cline { 6 - 9 } & & selisih & $\begin{array}{l}\% \\
\text { naik }\end{array}$ & selisih & $\begin{array}{l}\% \\
\text { naik }\end{array}$ \\
\hline $\begin{array}{l}\text { Hasrat keinginan untuk } \\
\text { berhasil belajar }\end{array}$ & 65,91 & 69,32 & 76,14 & 3,41 & 5,17 & 6,82 & 9,84 \\
\hline $\begin{array}{l}\text { Dorongan dan kebutuhan } \\
\text { untuk belajar }\end{array}$ & 70,08 & 75,76 & 78,03 & 5,68 & 8,11 & 2,27 & 3,00 \\
\hline $\begin{array}{l}\text { Harapan cita - cita masa } \\
\text { depan }\end{array}$ & 71,02 & 73,86 & 77,27 & 2,84 & 3,99 & 3,41 & 4,62 \\
\hline $\begin{array}{l}\text { Kegiatan yang menarik } \\
\text { dalam belajar }\end{array}$ & 70,45 & 76,14 & 79,92 & 5,69 & 8,08 & 3,78 & 4,96 \\
\hline Skor Rata - rata & 69,37 & 73,77 & 77,84 & 4,40 & 6,34 & 4,07 & 5,52 \\
\hline
\end{tabular}

Sumber : Data primer yang diolah.

Dari tabel 14 terlihat jelas adanya peningkatan Motivasi Belajar PKn siswa kelas X Akuntansi SMK Bhina Karya I Rongkop. Pada setiap indikator terjadi peningkatan yang signifikan. Secara detail data peningkatan motivasi belajar PKn dapat dilihat melalui grafik berikut:

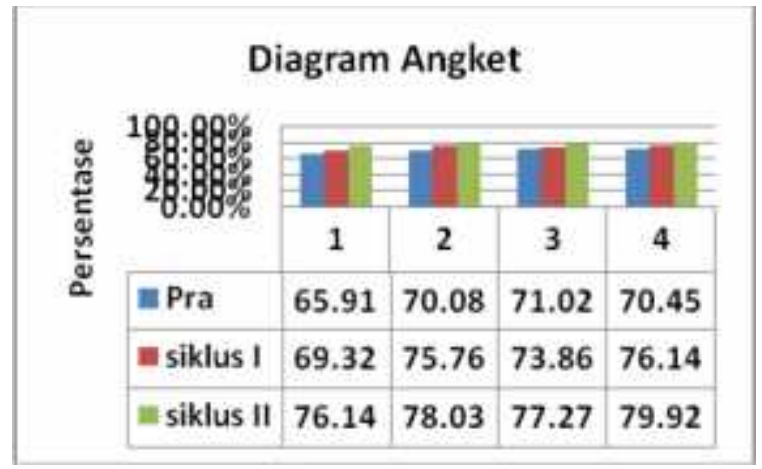

Keterangan:

1 : Hasrat keinginan untuk berhasil belajar

2 : Dorongan dan kebutuhan untuk belajar

3 : Harapan cita - cita masa depan

4 : Kegiatan yang menarik dalam belajar 
Berdasarkan data yang telah ditampilkan di atas, motivasi belajar sebelum menggunakan metode Think Pair Share ke Siklus I adalah 4,40\% sedangkan peningkatan persentase dari siklus I ke Siklus II yaitu 4,07 \%. Pada setiap siklus juga dilakukan observasi. Observasi ini dilakukan untuk mengetahui aktivitas-aktivitas yang dilakukan oleh siswa yang mencerminkan adanya motivasi belajar siswa. Selanjutnya data tersebut diolah lebih lanjut untuk mendapatkan angkaangka yang lebih mudah diinterpretasikan yaitu dengan cara memberikan skor sesuai dengan skor alternatif jawaban yang telah mencerminkan adanya motivasi belajar PKn. Sebelumnya telah dituliskan data hasil observasi pada masing-masing indikator. Berikut adalah data observasi tersebut.

Tabel 15. perbandingan data observasi pada Siklus I dan Siklus II.

\begin{tabular}{|c|c|c|c|c|}
\hline \multirow{2}{*}{ Indikator } & \multicolumn{2}{|c|}{ Skor \% } & \multicolumn{2}{c|}{ Peningkatan \% } \\
\cline { 2 - 5 } & Siklus I & Siklus II & Selisih & $\%$ kenaikan \\
\hline $\begin{array}{c}\text { Hasrat keinginan untuk berhasil } \\
\text { belajar }\end{array}$ & $70,45 \%$ & $76,14 \%$ & $5,69 \%$ & $8,08 \%$ \\
\hline $\begin{array}{c}\text { Dorongan dan kebutuhan untuk } \\
\text { belajar }\end{array}$ & $76,14 \%$ & $80,68 \%$ & $4,54 \%$ & $5,96 \%$ \\
\hline Harapan cita - cita masa depan & $72,73 \%$ & $76,14 \%$ & $3,41 \%$ & $4,69 \%$ \\
\hline $\begin{array}{c}\text { Kegiatan yang menarik dalam } \\
\text { belajar }\end{array}$ & $77,27 \%$ & $80,68 \%$ & $3,41 \%$ & $4,41 \%$ \\
\hline Skor Rata - rata & $74,15 \%$ & $78,41 \%$ & $4,26 \%$ & $5,74 \%$ \\
\hline
\end{tabular}

Sumber : Data primer yang diolah.

Dari tabel 14 jelas terlihat adanya peningkatan motivasi belajar siswa pada mata pelajaran PKn di SMK Bhina Karya I Rongkop. Peningkatan sebesar 4,26\% dengan persentase kenaikan $5,74 \%$, dari $74,15 \%$ pada siklus I menjadi $78,41 \%$ pada siklus II. Secara detail peningkatan motivasi belajar siswa dapat dilihat di grafik berikut:

Gambar 5. Diagram data observasi.

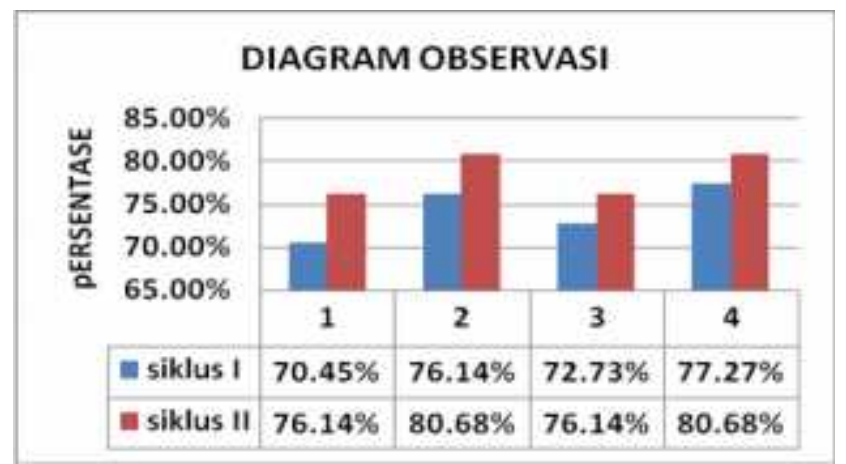




\section{Keterangan :}

1. Hasrat keinginan untuk berhasil belajar

2. Dorongan dan kebutuhan untuk belajar

3. Harapan cita-cita masa depan.

4. Kegiatan yang menarik dalam belajar.

Berdasarkan data yang telah ditampilkan di atas, baik data observassi maupun angket dan diperkuat dengan wawancara dapat dilanjutkan ke tahap berikutnya yaitu penarikan kesimpulan. Berikut ini penarikan kesimpulan dilakukan baik secara keseluruan motivasi belajar Mata pelajaran PKn maupun indikator-indikator yang melingkupinya:

a. Indikator hasrat keinginan untuk berhasil belajar.

Terjadi peningkatan skor dari sebelum menggunakan Think Pair Share ke Siklus I sebesar 3,41\% dengan persentase kenaikan 5,17\% sedangkan peningkatan dari siklus I ke siklus II sebesar 6,82\% dengan persentase kenaikan 9,84\%. Peningkatan skor motivasi belajar siswa juga ditunjukan dari observasi dimana terjadi peningkatan sebesar 5,69\% dengan persentase kenaikan 8,08 \% dari Siklus I ke Siklus II. Data angket maupun observasi indikator ini samasama mengalami peningkatan dan telah mencapai kriteria minimal $75 \%$. Metode pembelajaran Think Pair Share menuntut siswa untuk lebih bertanggungjawab terhadap tugas masing-masing sehingga mereka akan berusaha secara maksimal. Hal ini sejalan dengan pendapat Wina Sanjaya (2011:250) bahwa metode pembelajaran kooperatif dapat memberdayakan siswa untuk lebih bertanggungjawab dalam pembelajaran.

b. Indikator dorongan dan kebutuhan untuk belajar.

Skor sebelum menggunakan metode pembelajaran think pair share sebesar $65,91 \%$ dan pada siklus I menunjukan bahwa indikator dorongan dan kebutuhan untuk belajar sebesar 75,76\%. Sedangkan pada siklus II indikator ini meningkat menjadi 78,03\%, hal ini menujukan adanya peningkatan sebesar $5.68 \%$ dengan persentase kenaikan $8,11 \%$ sebelum siklus I dan siklus II. Dari siklus I ke siklus II mengalami kenaikan sebesar 2,27\% dengan persentase kenaikan 3,00\%. Selain itu, data observasi menjukan bahwa pada siklus I indikator dorongan dan kebutuhan untuk belajar sebesar 76,14\% dan pada siklus II mengalami peningkatan sebesar 4,54\% sehingga menjadi $80,68 \%$. Peningkatan ini terjadi karena siswa mulai terbiasa dan berani bertanya kepada guru untuk mencai pemecahan masalah dengan bertanya kepada guru sehingga dorongan siswa untuk belajar meningkat. 
c. Indikator harapan cita-cita masa depan

Terjadi peningkatan dari sebelum menggunakan metode think pair share ke siklus I sebesar 2,84\%, dari siklus I ke siklus II mengalami peningkatan sebesar 3,41\% dengan persentase kenaikan 4,62\% . Selaras dengan data tersebut, pada observasi terjadi peningkatan skor sebesar 3,41. Penerapan metode pembelajaran Think Pair Share ini menjadikan siswa lebih fokus untuk memperhatikan penjelasan guru dan menimbulkan komunikasi 2 arah antar siswa dan guru yang tampak pada saat penyampaian materi guru memberikan pertanyaan, hampir semua siswa menjawab dengan yakin. Dengan demikian siswa menjadi lebih cepat paham mengenai materi yang disampaikan oleh guru. Seperti yang diungkapkan oleh Wina sanjaya (2012 : 250) bahwa interaksi selama pembelajaran berlangsung dapat meningkatkan motivasi.

d. Indikator kegiatan yang menarik dalam belajar

Pada pra siklus ke siklus I indikator ini mengalami peningkatan sebesar 5,69\%, dari siklus I ke siklus II mengalami peningkatan 3,78\% yaitu dari skor 76,14\% menjadi 79,92\%. Sedangkan data observasi menujukan peningkatan sebesar 3,41\% dari data siklus I sebesar $77,27 \%$ ke siklus II menjadi sebesar $80,68 \%$. Berdasarkan data tersebut sebagian besar siswa tertarik dengan pembelajaran yang dilakukan menggunakan metode pembelajaran Think Pair Share karena siswa lebih aktif dan merasa tertantang untuk menyelesaikan kasus soal yang diberikan oleh guru. Di sisi lain siswa berani mengutarakan jawabannya dan menkonfirmasikan pertanyaan-pertanyaan dari teman-temannya

Bedasarkan hasil penelitian tersebut dapat disimpulkan bahwa penerapan metode pembelajaran Think Pair Share dapat meningkatkan motivasi belajar mata pelajaran Pkn siswa dengan mencapai minimal 75\% sesuai dengan yang diungkapkan Mulyasa (2006:174), bahwa pembelajaran dikatakn berhasil dan berkualitas apabila seluruhnya atau setidak-tidaknya sebagian besar $75 \%$ siswa terlibat aktif dalam proses pembelajaran.

Motivasi belajar siswa secara garis besar diperoleh peningkatan skor pada setiap indikatornya. Oleh karena itu, dengan ini telah terbukti bahwa dengan penerapan metode pembelajaran Think Pair Share dapat meningkatkan motivasi belajar siswa kelas X Akuntansi di SMK Bhina Karya I Rongkop terutama pada mata pelajaran PKn. 


\section{Kelebihan Penelitian ini}

Melalui penelitian tindakan kelas ini, baik siswa maupun guru dapat merasakan manfaatnya secara langsung. Hal ini dapat dilihat dengan adanya peningkatan motivasi siswa, diantaranya siswa lebih aktif dan bersemangat mengikuti pembelajaran. Peneliti mencoba mengumpulkan semua fakta, dan secara cermat menilai dan menguraikan masalahnya.

\section{Kesimpulan}

Berdasarkan hasil penelitian dan pembahasan dapat disimpulkan bahwa penerapan metode pembelajaran Think Pair Share dilaksanakan sesuai dengan langkah-langkah yang telah ditetapkan. Hal ini dibuktikan oleh pengamatan yang dilakukan dengan menggunakan lembar observasi yang telah dipersiapkan sebelumnya. Penerapan metode pembelajaran ini juga terbukti dapat meningkatkan motivasi belajar siswa kelas X Akuntansi di SMK Bhina Karya I Rongkop, terutama pada mata pelajaran PKn. Hal ini dibuktikan dengan adanya peningkatan persentase skor motivasi belajar siswa yang diambil melalui angket, observasi, maupun wawancara. Pada data angket diperoleh skor sebelum siklus I sebesar 69,37\% meningkat menjadi sebesar 73,77\%. Pada siklus I pembelajaran dengan menggunakan metode Think Pair Share terjadi peningkatan sebesar 4,40\% dengan persentase kenaikan sebesar 6,34\%. Pada siklus I ke siklus II terjadi peningkatan sebesar 4,07\% dengan persentase kenaikan 5,52\% atau meningkat dari 73,77\% pada siklus I menjadi sebesar $77,84 \%$ pada siklus II. Selanjutnya berdasarkan data observasi yang dilakukan pada siklus I dan siklus II dapat disimpulkan pula bahwa terjadi peningkatan skor motivasi belajar siswa sebesar 4,26 \% dimana skor pada siklus I sebesar 74,15\% meningkat menjadi $78,41 \%$ pada siklus II. Hal ini juga diperkuat dengan data wawancara yang dilakukan pasca penerapan metode pembelajaran Think Pair Share ini, dimana data yang diperoleh menunjukan hasil yang sama dengan data siswa ketika mengisi angket.

\section{Daftar Pustaka}

Nana Sudjana.1988. Penilaian Hasil Proses Belajar Mengajar. Bandung: PT. Remaja Rosdakarya

Trianto.S. 2007. Model-Model pembelajaran inovatif berorientasi konstruktivistik. Jakarta: Prestasi Pustaka. 
Anita Lie. 2004. Cooperative Learning: Mempraktikkan Cooperative Learning di Ruang-Ruang Kelas, Jakarta: Grasindo (Gramedia Widiasarana Indonesia).

Nurhadi, dkk. 2003. Pembelajaran Kontekstual dan Penerapannya dalam KBK. Malang:Universitas Negeri Malang.

Sardiman. A.M. 2007. Interaksi dan Motivasi Belajar Mengajar, Jakarta: PT. Raja Grafindo Persada.

1992. Interaksi Motivasi Belajar Mengajar, Jakarta: CV Rajawali

Slameto. 2010. Belajar dan Faktor Faktor Yang Mempengaruhinya, Jakarta : PT. Rineka Cipta

Winkel. W.1983. Psikologi Pendidikan dan Evaluasi Belajar, Jakarta : Gramedia.

Santrock, J.W. 2007.Psikologi Perkembangan.Edisi 11Jilid 1.Jakarta: Erlangga.

Brophy, J. 2004. Motivating Student to Learn. London : Lawrence Erlbaum Associates, Publishers.

Depdiknas. 2005. Pendidikan Kewarganegaraan, Strategi dan Metode Pembelajaran Pendidikan Kewarganegaraan, Jakarta : Depdiknas.

Wina Senjaya. 2006. Strategi Pembelajaran Berorientasi Proses Standar Pendidikan, Jakarta : Kencana Prima.

Sugiyono. 2012. Metode Penelitian Pendidikan (Pendekatan Kuantitatif Kualitatif, $R \&$ D). Bandung : ALFABETA.

Kasijan. Z, 1984. Psikologi Pendidikan. Surabaya: PT. Bima Aksara.

Oemar Hamalik. 1990. Psikologi Belajar dan Mengajar. Bandung: CV Sinar Baru

Suryosubroto. 1988. Dasar-dasar untuk Pendidikan di Sekolah. Jakarta: PT Prima Karya

Depdiknas. 2005. Kamus Besar Bahasa Indonesia, Jakarta : Balai Pustaka.

Mulyasa. 2006. Menjadi Guru Profesional Menciptakan Pembelajaran Kreatif dan Menyenangkan. Bandung : PT. Remaja Rosdakarya.

Suharsimi Arikunto. 2002. Dasar- Dasar Evaluasi Pendidikan. Jakarta: Bumi Aksara. 